\title{
Upaya Meningkatkan Kompetensi Guru dalam Melaksanakan Pembelajaran melalui Supervisi Klinis Kepala Sekolah di SDN 06 Woja Kabupaten Dompu Tahun Pembelajaran 2020-2021
}

\author{
Abdurrahman \\ SDN 06 Woja, Kabupaten Dompu, Nusa Tenggara Barat \\ E-mail: abdurrahman06woja@gmail.com
}

\begin{tabular}{l}
\hline Article Info \\
\hline Article History \\
Received: 2021-08-27 \\
Revised: 2021-09-25 \\
Published: 2021-10-26 \\
Keywords: \\
Teacher Competence; \\
Learning process; \\
Clinical Supervision; \\
Principal. \\
\\
\\
Artikel Info \\
\hline Sejarah Artikel \\
Diterima: 2021-08-27 \\
Direvisi: 2021-09-25 \\
Dipublikasi: 2021-10-26
\end{tabular}

Kata kunci:

Kompetensi Guru; Proses Pembelajaran; Supervisi Klinis; Kepala Sekolah.

\begin{abstract}
The success of education in schools is largely determined by the success of the principal in managing the available education personnel at the school. In this case, increasing productivity and school work performance can be done by improving the behavior of education personnel in schools through various applications of modern personnel management concepts and techniques. stay in a pleasant condition, The purpose of this school action research (PTS) is to find out the extent to which teacher competence increases in carrying out learning through clinical supervision of school principals at SDN 06 Woja, Dompu Regency in the 2020-2021 learning year, in this school action research (PTS) carried out in 3 cycles, from the results of the actions taken it is proven to be able to improve Teacher Competence by achieving ideal standards. From $72.92 \%$ in the first cycle, it can increase to $77.08 \%$ in the second cycle, and $82.92 \%$ in the third cycle. The results of this action research show that coaching through the clinical supervision of the principal can improve teacher competence in carrying out learning with completeness reaching 100\%.
\end{abstract}

\section{PENDAHULUAN}

Kompetensi merupakan spesifikasi dari kemampuan, keterampilan, dan sikap yang dimiliki seseorang serta penerapannya di dalam pekerjaan, sesuai dengan standar kinerja yang dibutuhkan oleha lapanagan (Ditjen Dikdasmen, 2004:4). Berdasarkan pendapat tersebut seorang yang berkerja sebagai guru, yang menurut Undang-Undang Guru tahun 2006 merupakan pekerjaan profesional, guru harus memenuhi stndar-standar minimal yang dibutuhkan oleh Depdiknas, berdasarkan hal tersebut, Depdiknas menentukan bagian-bagian yang harus dikuasai oleh guru dalam rangka memenuhi standar kompetensi guru. Komponen-komponen standar komptemsi guu, antara lain: (1) Komponen Kompetensi Pengelolaan Pembelajaran dan Wawasan Kependidikan, (2) Komponen Kompetensi Akademik/ Vokasional sesuai materi pmebelajaran, (3) Pengembangan profesi. Selain ketiga komponen tersebut, seorang guru harus memiliki sikap dan kepribadian tersebut senantiasa melekat pada setiap komponen yang menunjang profesi guru, Pada hakekatnya supervisi sangat diperlukan oleh para guru, karena mereka menginginkan keberhasilan pelaksanaan fungsi dan tugas mengajarnya. Akan tetapi mereka menentang pelaksanaan supervisi 
karena cara yang digunakan umumnya tidak banyak membantu mereka.

Beberapa hal dianggap pentingnya kegiatan supervisi klinis adalah sebagai berikut: (1) Supervisi disamakan dengan evaluasi. Guru cenderung menjadi gerah apabila mereka mengetahui akan dievaluasi. Terutama jika hasil evaluasinya dirasakan negatif dapat menurunkan semangat kerja guru yang berakibat rendahnya kualitas proses belajar mengajar, (2) Pada umumnya supervisi dilakukan atas dasar kemauan supervisor, tidak atas kemauan atau kebutuhan guru; (3) Karena supervisi cenderung bersifat birokratis dan evaluatif; maka guru-guru cenderung menghindari disupervisi. Mereka juga berpendapat, bahwa supervisor lebih banyak bicara dan mengarahkan daripada menanyakan serta mendengarkan apa yang menjadi pusat perhatian (concerns) dan kebutuhan guru; (4) Pada umumnya supervisor lebih banyak mengawasi (controlling) daripada berbagi ide dan pengalaman (sharing ideas and experiences). Guru-guru merasa bahwa supervisor tidak mempercayai kemampuan mereka; (5) kadangkadang supervisor tidak tahu apa sebenarnya yang harus ia amati dan nilai. Akibatnya, data hasil pengamatan tidak sistematis, bersifat subjektif dan tidak jelas yang dapat menimbulkan konflik antara supervisor dan guru.

kecenderungan dewasa ini untuk kembali pada pemikiran bahwa siswa akan belajar lebih baik jika lingkungan diciptakan alamiah. Belajar akan lebih bermakna jika siswa mengalami apa yang dipelajarinya, bukan memgetahuinya. Pembelajaran yang berorientasi pada penguasaan materi terbukti berhasil dalam kompetisi menggingat jangka pendek tetapi gagal dalam membekali anak memecahkan persoalan dalam kehidupan jangka panjang. Guru adalah salah satu di antara faktor pendidikan yang memiliki peranan yang paling strategis, sebab gurulah sebetulnya yang paling menentukan di dalam terjadinya proses belajar mengajar. Di tangan guru yang cekatan fasilitas dan sarana yang kurang memadai dapat diatasi, tetapi sebaliknya ditangan guru yang kurang cakap, sarana, dan fasilitas yang canggih tidak banyak memberi manfaat. Berangkat dari masalah di atas, maka langkah pertama yang dilakukan untuk memperbaiki kualitas pendidikan adalah dengan memperbaiki kualitas tenaga pendidiknya terlebih dahulu.

Guru merupakan orang pertama mencerdaskan manusia, orang yang memberi bekal penge- tahuan, pengalaman, dan menanamkan nilainilai, budaya, dan agama terhadap anak didik, dalam proses pendidikan guru memegang peranan penting setelah orang tua dan keluarga di rumah. Di lembaga pendidikan guru menjadi orang pertama, bertugas membimbing, mengajar dan melatih anak didik mencapai kedewasaan.

Kondisi seperti yang diharapkan di atas di kalangan guru masih banyak yang belum menguasainya, hal ini disebabkan karena ketidak mampuan guru dalam mengelola pembelajaran terutama dalam proses pembelajaran yang belum mampu meningkatkan hasil belajar siswa melalui Supervisi Klinis Kepala Sekolah. Kondisi seperti ini terjadi pada guru di SDN No 06 Woja Kab. Dompu yang masih banyak guru belum bisa melaksanakan Peningkatan Kompetensi Guru Dalam Melaksanakan Pembelajaran, akibatnya siswa merasa kesulitan dalam meningkatkan prestasinya. Oleh karena itu penulis perlu melakukan suatu penelitian tindakan sekolah dengan melakukan suatu upaya membantu guru dalam meningkatkan kualitas pembelajaran di kelas, untuk itu ditentukan tujuan dalam penelitian ini yaitu: Bagaimanakah Meningkatkan Kompetensi Guru dalam Melaksanakan Pembelajaran melalui Supervisi Klinis Kepala Sekolah di SDN No 06 Woja Kab. Dompu Tahun Pembelajaran 2020-2021?

\section{METODE PENELITIAN}

Penelitian ini merupakan Penelitian Tindakan Sekolah (PTS), dengan subyek Guru SDN No 06 Woja Kabupaten Dompu tahun pembelajaran 2020-2021, Jumlah guru yang menjadi sampel dalam penelitian ini terdiri atas 12 orang guru baik yang berstatus Guru Tetap (GT) maupun yang Guru Tidak Tetap (GTT). Rancangan yang ditetapkan dalam penelitian ini terdiri atas: a) Kegiatan dilaksanakan dalam Semester Ganjil tahun pembelajaran 2020-2021, b) Tindakan dilaksanakan dalam 3 siklus dengan durasi penelitian selama 6 pekan efektif dilaksanakan sejak tanggal 10 Agustus 2020 s.d 14 September 2020 , c) rancangan pelaksanaan penelitian dilakukan dalam 3 siklus yang meliputi: (1) perencanaan, (2) tindakan, (3) pengamatan, dan (4) refleksi, adapun teknik pengumpulan data yang digunakan dalam penelitian ini menggunakan Observasi dan Tes, sedangkan untuk indicator keberhasilan penelitian ditandai dengan peningkatan Kompetensi Guru dalam Melaksanakan Pembelajaran mencapai $>85 \%$ (Sekolah yang diteliti) telah mencapai ketuntasan dengan nilai rata-rata 75 , dengan kriteria telah 
memenuhi harapan ideal seperti yang disyaratkan dalam manajemen berbasis sekolah (MBS).

\section{HASIL DAN PEMBAHASAN}

\section{A. Paparan Data dan Temuan dalam Penelitian}

1) Perencanaan Tindakan

Tindakan yang dilakukan oleh peneliti pada tahap ini diantaranya:

a) Menyusun instrumen penilaian sesuai dengan standar pengelolaan pendidikan (8 standar isi pendidikan).

b) Menyusun instrumen monitoring.

c) Sosialisasi kepada guru.

d) Melaksanakan tindakan sekolah melalui Supervisi Klinis Kepala Sekolah.

e) Melaksanakan refleksi pada siklus pertama.

f) Menyusun strategi pembinaan pada siklus ke dua berdasarkan refleksi siklus pertama.

g) Melaksanakan pembinaan melalui supervisi pada siklus kedua.

h) Melaksanakan Observasi.

i) Melaksanakan refleksi pada siklus kedua.

j) Menyusun strategi pembinaan melalui Supervisi Klinis Kepala Sekolah pada siklus ketiga berdasar refleksi siklus kedua.

k) Melaksanakan pembinaan melalui Supervisi Klinis pada siklus ketiga.

1) Melaksanakan Observasi.

m) Melaksanakan refleksi pada siklus ketiga.

n) Menyusun laporan.

2) Pelaksanaan Tindakan dan Pengamatan Pelaksanaan tindakan sekolah dalam penelitian ini melalui 3 siklus yang terdiri dari tiga kali pertemuan, Waktu yang digunakan setiap kali pertemuan adalah $2 \mathrm{x}$ 45 menit. Pertemuan pertama dilaksanakan pada tanggal 10 s.d 19 Agustus 2020, dan siklus kedua pada tanggal 24 s.d 31 Agustus 2020, siklus ketiga pada tanggal 07 s.d 14 September 2020. Penelitian tindakan sekolah dilaksanakan sesuai dengan prosedur rencana pembelajaran dan skenario pembelajaran.

\section{SIKLUS I}

1. Tahap Perencanaan

Pada tahap ini peneliti mempersiapkan beberapa perangkat pembinaan berupa perencanaan pembelajaran, pelaksanaan pembelajaran yang sudah distandarisasi dan alat-alat pengajaran lain yang mendukung.

2. Tahap Pelaksanaan Kegiatan

Pelaksanaan kegiatan pembinaan untuk siklus I dilaksanakan pada tanggal 10 s.d 19 Agustus 2020, di SDN No 06 Woja Kab. Dompu Tahun Pembelajaran 2020-2021 dengan jumlah guru 12 orang. Dalam hal ini peneliti bertindak sebagai kepala sekolah. Adapun proses pembinaan mengacu pada rencana pembinaan melalui Supervisi Klinis yang telah dipersiapkan, dan dilaksa-nakan pada saat proses belajar mengajar berlangsung.

Dari data dijelaskan bahwa dengan penerapan yang dilakukan oleh Supervisi Klinis Kepala Sekolah diperoleh nilai ratarata peningkatan Kompetensi guru adalah $72.92 \%$. Hasil tersebut menunjukkan bahwa pada siklus pertama secara keseluruhan belum tuntas, karena guru yang memperoleh nilai $\geq 65$ hanya sebesar $33.33 \%$ atau ada 4 orang dari 12 guru yang tuntas, hasil ini tentu lebih kecil dari persentase ketuntasan yang dikehendaki yaitu sebesar $85 \%$, hal ini disebabkan karena banyak guru yang belum memahami dan merasa baru dengan Supervisi Klinis sehingga mereka belum dapat memahaminya dengan baik.

\section{Refleksi}

Dalam pelaksanaan kegiatan belajar mengajar diperoleh informasi dari hasil pengamatan sebagai berikut:

a. Kepala Sekolah kurang baik dalam memotivasi guru dan dalam menyampaikan tujuan pembinaan

b. Kepala Sekolah kurang baik dalam pengelolaan waktu

c. Guru kurang begitu antusias selama pembinaan berlangsung.

4. Revisi Rancangan

Pelaksanaan kegiatan pembinaan pada siklus I ini masih terdapat kekurangan, sehingga perlu adanya revisi untuk dilakukan pada siklus berikutnya.

a. Kepala Sekolah perlu lebih terampil dalam memotivasi guru dan lebih jelas dalam menyampaikan tujuan pembinaan. Dimana guru diajak untuk terlibat langsung dalam setiap kegiatan yang akan dilakukan. 
b. Kepala Sekolah perlu mendistribusikan waktu secara baik dengan menambahkan informasi-informasi yang dirasa perlu dan memberi catatan.

c. Kepala Sekolah harus lebih terampil dan bersemangat dalam memotivasi guru sehingga guru bisa lebih antusias.

\section{SIKLUS II}

1. Tahap perencanaan

Pada tahap ini peneliti mempersiapkan perangkat pembinaan yang terdiri dari rencana pembinaan 2 , soal tes formatif II dan alat-alat pembinaan lain yang mendukung.

2. Tahap pelaksanaan Kegiatan

Pelaksanaan kegiatan pembinaan untuk siklus II dilaksanakan pada tanggal 24 s.d 31 Agustus 2020, di SDN No 06 Woja Kab. Dompu Tahun Pembelajaran 2020-2021. Dalam hal ini peneliti bertindak sebagai kepala sekolah. Adapun proses pembinaan mengacu pada rencana pembinaan dengan memperhatikan revisi pada siklus I, sehingga kesalahan atau kekurangan pada siklus I tidak terulang lagi pada siklus II. Penelitian tindakan sekolah ini dilaksanakan sesuai dengan prosedur rencana pembinaan dan pelaksanaan pembinaan.

$77.08 \%$ dan dari 12 orang guru sudah 9 orang yang sudah tuntas ( $75 \%$ ) . Hasil ini menunjukkan bahwa pada siklus II ini hasil pembinaan melalui supervisi klinis kepala sekolah telah mengalami peningkatan lebih baik dari siklus I. Adanya peningkatan Kompetensi Guru ini karena kepala sekolah telah menginformasikan bahwa setiap akhir pembinaan akan diadakan penilaian sehingga pada pertemuan berikutnya guru lebih termotivasi untuk meningkatkan kinerjanya. Selain itu para guru juga sudah mulai mengerti apa yang dimaksudkan dan diinginkan oleh kepala sekolah dalam melakukan pembinaan melalui Supervisi Klinis Kepala Sekolah.

3. Refleksi

Dalam pelaksanaan kegiatan belajar mengajar diperoleh informasi dari hasil pengamatan sebagai berikut:

a. Kepala Sekolah sudah cukup baik dalam memotivasi guru dalam proses penelitian yang dilakukan.

b. Kepala Sekolah sudah cukup baik dalam pengelolaan waktu c. Guru sudah cukup antusias selama pembinaan berlangsung.

d. Memotivasi kepala sekolah.

e. guru sudah cukup mampu dalam menyusun perencanaan dan pelaksanaan program sekolah, merumuskan kesimpulan/menemukan konsep.

\section{Revisi Pelaksanaaan}

Pelaksanaan pembinaan pada siklus II ini masih terdapat kekurangan-kekurangan. Maka perlu adanya revisi untuk dilaksanakan pada siklus III antara lain:

a. Kepala Sekolah dalam memberikan pembinaan kepada guru hendaknya dapat membuat para guru termotivasi dalam membuat program dan rencana pembelajaran.

b. Kepala Sekolah harus lebih dekat dengan guru sehingga tidak ada perasaan takut/ malu dalam diri guru terutama dalam bertanya tentang masalah yang dihadapi oleh sekolah.

c. Kepala Sekolah harus lebih sabar dalam melakukan pembinan kepada guru terutama dalam merumuskan kesimpulan / menemukan konsep.

d. Kepala Sekolah harus mendistribusikan waktu secara baik sehingga kegiatan pembinaan dapat berjalan efektif sesuai dengan yang diharapkan.

e. Kepala Sekolah sebaiknya menambah lebih banyak contoh-contoh adminsitrasi pembelajaran dengan formatformat yang sudah distandardisasi oleh Kementrian Pendidikan dan Kebudayaan, dalam hal ini Lembaga Penjaminan Mutu Pendidikan (LPMP) baik di Tingkat Provinsi maupun tingkat Pusat.

\section{SIKLUS III}

1. Tahap Perencanaan

Pada tahap ini peneliti mempersiapkan perangkat pembinaan yang berkaitan dengan peningkatan Kompetensi Guru dalam Melaksanakan Pembelajaran di sekolah 3, soal tes formatif 3 dan alat-alat pembinaan lainnya yang mendukung.

2. Tahap kegiatan dan pengamatan

Pelaksanaan kegiatan pembinaan untuk siklus III dilaksanakan pada tanggal 07 s.d 14 Setember 2020, di SDN No 06 Woja Kab. Dompu Tahun Pembelajaran 2020-2021, dengan jumlah 12 orang guru. Dalam hal ini peneliti bertindak sebagai Kepala Sekolah. Adapun proses pembinaaan 
mengacu pada rencana pembinaan dengan memperhatikan revisi pada siklus II, sehingga kesalahan atau kekurangan pada siklus II tidak terulang lagi pada siklus III. Pengamatan (observasi) dilaksanakan bersamaan dengan proses belajar mengajar di sekolah.

Nilai rata-rata tes formatif sebesar $82.93 \%$ dan dari 12 orang guru semuanya telah mencapai ketuntasan dalam melaksanakan pembelajaran. Maka secara kelompok ketuntasan telah mencapai 100 $\%$ ( termasuk kategori tuntas ). Hasil pada siklus III ini mengalami peningkatan lebih baik dari siklus II. Adanya peningkatan hasil pembinaan pada siklus III ini dipengaruhi oleh adanya peningkatan kemampuan kepala sekolah dalam menerapkan pembinaan melalui Supervisi Klinis sehingga guru menjadi lebih memahami tugasnya masing masing dan dapat meningkatkan kinerjanya. Di samping itu ketuntasan ini juga dipengaruhi oleh kerja sama dari kepala sekolah, dan guru dalam Melaksanakan Pembelajaran.

3. Refleksi

Pada tahap ini dikaji apa yang telah terlaksana dengan baik maupun yang masih kurang baik dalam proses pembinaan melalui penerapan Supervisi Klinis. Dari data-data yang telah diperoleh dapat duraikan sebagai berikut:

a. Selama proses pembinaan kepala sekolah telah melaksanakan semua pembinaan dengan baik. Meskipun ada beberapa aspek yang belum sempurna, tetapi persentase pelaksanaannya untuk masing-masing aspek cukup besar.

b. Berdasarkan data hasil pengamatan diketahui bahwa guru aktif selama proses pembinaan berlangsung.

c. Kekurangan pada siklus-siklus sebelumnya sudah mengalami perbaikan dan peningkatan sehingga menjadi lebih baik.

d. Hasil pembinaan kepala sekolah melalui penerapan Supervisi Klinis pada siklus III mencapai ketuntasan.

4. Revisi Pelaksanaan

Pada siklus III kepala sekolah telah melaksanakan pembinaan dengan baik dan dilihat dari peningkatan Kompetensi Guru pelaksanaan pembinaan sudah berjalan dengan baik. Maka tidak diperlukan revisi terlalu banyak, tetapi yang perlu diperhatikan untuk tindakan selanjutnya adalah memaksimalkan dan mempertahankan apa yang telah ada dengan tujuan agar pada pelaksanaan pembinaan selanjutnya baik melalui penerapan supervisi kepala sekolah dapat meningkatkan Kompetensi Guru sehingga tujuan pembinaan sebagai upaya meningkatkan mutu pendidikan secara umum dapat tercapai.

\section{B. Analisis Hasil Kegiatan}

1) Analisis Data Deskriptif Kuantitatif

a. Pencapaian Peningkatan Kompetensi Guru sebelum sebelum diberi tindakan

$$
=\frac{875}{1200} \times 100 \%=72,92 \%
$$

b. Peningkatan Kompetensi Guru dalam Melaksanakan Pembelajaran setelah diberi tindakan melalui Supervisi Klinis.

$=\underline{925} \times 100 \%=77,08 \%$ 1200

c. Peningkatan Kompetensi Guru dalam mengolah pembelajaran setelah diberi tindakan melalui Supervisi Klinis Kepala Sekolah

$$
=\underline{995} \times 100 \%=82,92 \%
$$$$
1200
$$

Dari hasil analisis tersebut dapat disimpulkan bahwa:

a. Terjadi peningkatan Kompetensi Guru setelah diberi pembinaan melalui Supervisi Klinis yaitu peningkatan Kompetensi Guru dalam Melaksanakan Pembelajaran: 72,92 $\%$ menjadi $77,08 \%$ ada kenaikan sebesar $=4,16 \%$

b. Dari sebelum pembinaan ( siklus 1 ) dan setelah pembinaan oleh kepala sekolah sampai dengan ( siklus 2 ) 72,92 \% menjadi $77,08 \%$, dan siklus ke 3 juga mengalami kenaikan menjadi: 82,92 \% $77,08 \%=5,84 \%$

c. Rata - rata peningkatan Kompetensi Guru dalam Melaksanakan Pembelajaran sebelum diberi pembinaan 33,33\% naik menjadi $100 \%$.

2) Refleksi dan Temuan

Berdasarkan pelaksanaan pembinaan yang telah dilakukan kepala sekolah kepada guru melalui Supervisi Klinis, maka hasil observasi nilai, dapat dikatakan sebagai berikut :

a. Pertemuan pertama kegiatan pembinaan belum berhasil karena dalam pembinaan kepala sekolah masih terlihat guru belum 
begitu antusias karena mereka masih menganggap pembinaan kepala sekolah tersebut merupakan tugas baru yang diembannya.

b. Pembinaan yang dilakukan melalui Supervisi Klinis, dalam hal peningkatan Kompetensi Guru dalam Melaksanakan Pembelajaran belum tampak, sehingga hasil yang dicapai tidak tuntas.

c. Mungkin karena proses pembinaan melalui Supervisi Klinis baru mereka laksanakan sehingga guru merasa kaku dalam menerapkannya.

d. Akan tetapi setelah dijelaskan, mereka bisa mengerti dan buktinya pada pertemuan kedua proses pembinaan kepala sekolah berjalan baik, semua guru aktif dan lebihlebih setelah ada rubrik penilaian proses, semua guru antusias untuk mengikutinya dan telah mencapai ketuntasan.

\section{Pembahasan Hasil Penelitian}

Berikut disajikan beberapa pembahasan dalam pelaksanaan penelitian ini:

1. Peningkatan Kompetensi Guru dalam Melaksanakan Pembelajaran.

Melalui hasil penelitian ini menunjukkan bahwa pembinaan melalui Supervisi Klinis memiliki dampak positif dalam meningkatkan kinerja guru, hal ini dapat dilihat dari semakin mantapnya pemahaman guru terhadap pembinaan yang disampaikan kepala sekolah (melaksanakan pembelajaran meningkat dari siklus I, II, dan II ) yaitu masing-masing $72,92 \%$; 77,08 \%: 82,92 \% secara kelompok dikatakan tuntas

2. Kemampuan kepala sekolah dalam meningkatkan Kompetensi Guru dalam Melaksanakan Pembelajaran.

Berdasarkan analisis data, diperoleh aktivitas guru dalam meningkatkan kinerjanya dalam setiap siklus mengalami peningkatan. Hal ini berdampak positif terhadap capaian mutu sekolah yaitu dapat ditunjukkan dengan meningkatnya nilai rata-rata guru pada setiap siklus yang terus mengalami peningkatan.

3. Aktivitas kepala sekolah dan guru dalam Pembinaan melalui Supervisi Klinis.

Berdasarkan analisis data, diperoleh aktivitas kepala sekolah dan guru yang paling dominan dalam kegiatan pembinaan adalah bekerja dengan menggunakan alat/ media, mendengarkan/ memperhatikan penjelasan kepala sekolah, dan diskusi antar antar guru dan kepala sekolah. Jadi dapat dikatakan bahwa aktivitas guru dapat dikategorikan aktif, Sedangkan untuk aktivitas kepala sekolah selama pembinaan telah melaksanakan langkahlangkah metode pembinaan melalui Supervisi Klinis dengan baik. Hal ini terlihat dari aktivitas guru yang muncul di antaranya aktivitas membuat dan merencanakan program pembelajaran, melaksanakan, memberi umpan balik/ evaluasi/ tanya jawab di mana presentase untuk aktivitas di atas cukup besar.

Berdasarkan hasil penelitian $\mathrm{di}$ atas, peningkatan Kompetensi Guru dalam Melaksanakan Pembelajaran melalui Supervisi Klinis Kepala Sekolah hasilnya cukup baik. Hal itu tampak pada pertemuan dari 12 orang guru yang ada pada saat penelitian ini dilakukan nilai rata rata mencapai $72,92 \%$ meningkat menjadi 77,08 $\%$ pada siklus 2 siklus ke 3 meningkatan menjadi 82,92 \%, dan dari analisis data di atas bahwa pembinaan kepala sekolah melalui Supervisi Klinis efektif diterapkan dalam upaya meningkatkan Kompetensi Guru dalam Melaksanakan Pembelajaran, yang berarti proses pembinaan kepala sekolah lebih berhasil dan dapat meningkatkan Kompetensi Guru dalam Melaksanakan Pembelajaran di SDN No 06 Woja Kab. Dompu, oleh karena itu diharapkan kepada para kepala sekolah dapat melaksanakan pembinaan melalui Supervisi Klinis secara berkelanjutan.

Berdasarkan Permen No 13 Tahun 2007 tentang kompetensi kepala sekolah, dapat meningkatkan kinerja guru, serta dapat mengorganisasikan sekolah kearah perubahan yang diinginkan telah mencapai 85 $\%$ ketercapaiannya, maka Kompetensi Guru dalam Melaksanakan Pembelajaran dengan menerapkan Supervisi Klinis tersebut dikatakan efektif. Dengan demikian maka hipotesis yang diajukan di atas dapat diterima.

\section{SIMPULAN DAN SARAN}

\section{A. Simpulan}

Berdasarkan analisis hasil penelitian dan diskusi dapat disimpulkan sebagai berikut:

1. Pembinaan kepala sekolah dalam upaya meningkatkan Kompetensi Guru dalam Melaksanakan Pembelajaran melalui 
penerapan Supervisi Klinis menunjukan peningkatan pada tiap-tiap putaran (Siklus).

2. Aktivitas dalam kegiatan pembinaan menunjukan bahwa seluruh guru dapat meningkatkan kinerjanya dengan baik dalam setiap aspek.

3. Peningkatan mutu sekolah oleh kepala sekolah melalui melalui Supervisi Klinis ini menunjukan peningkatan pada tiap-tiap putarannya $(72,92 \%$ pada putaran 1 ; $77,08 \%$ pada putaran $2 ; 82,92 \%$ pada putaran 3).

4. Aktivitas guru menunjukan bahwa kegiatan pembinaan melalui penerapan Supervisi Klinis bermanfaat dan dapat membantu guru untuk lebih muda memahami konsep peran dan fungsi guru sehingga peningkatan lingkungan belajar yang efektif di sekolah dapat berjalan baik, dan dengan demikian peningkatan capaian mutu sekolah dapat ditingkatkan.

\section{B. Saran}

Setelah melakukan penelitian maka direkomendasikan beberapa saran demi perbaikan penelitian ini kedepannya:

1. Penelitian perlu dilanjutkan dengan serangkaian penelitian yang mengembangkan alat ukur keberhasilan yang lebih reliabel agar dapat menggambarkan peningkatan Kompetensi Guru dengan baik sehingga mutu pendidikan dapat ditingkatkan.

2. Pembinaan kepala sekolah melalui penerapan Supervisi Klinis diperlukan perhatian penuh dan disiplin yang tinggi pada setiap langkah pembinaan,dan perencanaan yang matang misalnya dalam pengalokasian waktu dan pemilihan konsep yang sesuai.

3. Kepada guru diharapkan selalu mengikuti perkembangan jaman, terutama dengan membaca hasil karya para akhli sehingga tidak ketinggalan dengan daerah lain, dalam meningkatkan mutu pendidikan, sebagai tanggung jawab bersama memajukan pendidikan.

\section{DAFTAR RUJUKAN}

A. Gafar Hidayat, Muhammad, Taufik, \& Tati Haryati. (2021). Analisis Pelaksanaan BDR (Belajar dari Rumah) Sekolah Dasar pada Masa Pandemi Covid 19 di Desa Teke Kecamatan Palibelo Kabupaten Bima. JIIP -
Jurnal Ilmiah Ilmu Pendidikan, 4(6), 390-397. Retrieved

from http://jiip.stkipyapisdompu.ac.id/jiip/index. $\mathrm{php} /$ IIIP/article/view/282

Arikunto, Suharsimi, 2007. Penelitian Tindakan Kelas .Jakarta: PT.Bumi Aksara.

Arikunto, Suharsimi. (2002). Dasar-dasar Arends, Richard, 1977. Classroom instruction and management.New York: Mc.Graw-Hill Companies,inc.

Budiman. (2021). Analisis Validitas dan Reliabilitas Perangkat Pembelajaran Model Penemuan terbimbing berbasis Home Visit. JIIP - Jurnal Ilmiah Ilmu Pendidikan, 4(6), 450-454. Retrieved from http://jiip.stkipyapisdompu.ac.id/jiip/index. $\mathrm{php} / \mathrm{IIIP} /$ article/view/304

Depdikbud,1993.Kurikulum sekolah menengah umum dan garis garis besar program pengajaran ( GBPP) mata pelajaran Bahasa Indonesia . Jakarta:Depdikbud.

Ida Faridah. (2021). Pengaruh Kompetensi Profesional Terhadap Motivasi Kerja Guru SD di Gugus Rujakbeling Kecamatan Kebumen Kabupaten Kebumen .JIIP - Jurnal Ilmiah Ilmu Pendidikan,4(6), 398-405. Retrieved from http://jiip.stkipyapisdompu.ac.id/jiip/index. php/JIIP/article/view/297

Noviyanti, Suharyanto, \& Rajaminsah. (2021). Supervisi Kepala Sekolah dalam Meningkatkan Kompetensi Profesional Guru di SMA Kartika XIX-1 dan SMA PGII 2 Kota Bandung.JIIP - Jurnal Ilmiah Ilmu Pendidikan, 4(6), 415-423. Retrieved from http://jiip.stkipyapisdompu.ac.id/jiip/index. $\mathrm{php} / \mathrm{IIIP} /$ article/view/299

Oemar Hamalik. 2001. Proses Belajar Mengajar. Jakarta: PT Bumi Aksara

Sardiman, A. M. 2001. Interaksi dan Motivasi Belajar Mengajar. Jakarta : PT Rajagrasindo Persada.

Slameto, 2003. Belajar dan Faktor-faktor Yang Mempengaruhinya. Rineka Cipta. Jakarta.

Sudirman, Dkk. (1991). Ilmu Pendidikan. Bandung: Remaja Rosdakarya 
Sudjana, 1998. Dasar-Dasar Proses Belajar Mengajar. Sinar Barn Algesindo. Ban dung.

Suparno, P. 1997. Filsafat Konstruktivisme Dalam Pendidikan. Yogyakarta : Kanisius.

Usman, Moh. Uzer. (1994). Menjadi Guru Profesional. Bandung: Pt Remaja Rosdakarya.

Yasin, I. (2021). Problem Kultural Peningkatan Mutu Pendidikan di Indonesia: Perspektif
Total Quality Management. Ainara Journal (Jurnal Penelitian Dan PKM Bidang Ilmu Pendidikan), 2(3), 239-246. https://doi.org/10.54371/ainj.v2i3.87

Yusnarti, M., \& Suryaningsih, L. (2021). Pengaruh Model Pembelajaran Role Playing Terhadap Hasil Belajar Siswa Sekolah Dasar. Ainara Journal (Jurnal Penelitian Dan PKM Bidang Ilmu Pendidikan), 2(3), 253-261. https://doi.org/10.54371/ainj.v2i3.89 